\author{
Zeynep Yaprak \\ Fatma Hayta \\ İbrahim Halil Yaprak
}

Dicle University, Diyarbakir-Turkey

zeynep_yaprakeyahoo.com

f hayta@hotmail.com

ibrahimyaprak@hotmail.com

http://dx.doi.org/10.12739/NWSA.2013.8.4.4C0173

\title{
A CONTRAST ANALYSIS OF LANGUAGE LEARNING AND VOCABULARY LEARNING STRATEGIES USED BY GERMAN LANGUAGE AND ENGLISH LANGUAGE LEARNERS
}

\begin{abstract}
The purpose of the present study was to explore foreign language students' (German-English) tendency to employ Language Learning strategies (LLS) and Vocabulary Learning strategies (VLS) in terms of gender, proficiency, and length of language learning. The participants included 255 foreign language students studying at a state University. As a tool a questionnaire was administered to undergraduate students. Findings of the study revealed that the students of both field made use of both LLS and VLS to a certain extent. In German Language department, female students were found to use LLS and VLS more frequently than male students, while no significant difference was found between female and male students in terms of strategy use in ELT department. More experienced students exploited these strategies more frequently than less experienced students.
\end{abstract}

Keywords: LLS, VLS, Proficiency, Autonomy, Foreign Language Teaching

\section{ALMAN Dİİ VE İNGILİZ DİLI BÖLÜMÜ ÖĞRETMEN ADAYLARININ DİL VE KELIME ÖĞRENME STRATEJILERİNI KULLLANIMLARININ KARŞILAŞTIRILMASI}

\section{ÖZET}

Öğrencilerinin dil öğrenme stratejileri (LÖS) ve kelime öğrenme stratejilerini(KÖS) kullanmaya yatkınlıklarını cinsiyet, yeterlilik ve öğrenme süresinin uzunluğu açısından ölçmeyi amaçlamıştır. Çalışmaya bir devlet üniversitesinin Yabancl Diller bölümünden 255 öğrenci katılmıştır. Ölçme aracı olarak öğrencilere anket uygulanmıştır. Çalışmanın sonucunda öğrencilerin önemli ölçüde öğrenme stratejilerini ve kelime öğrenme stratejilerini kullandıkları görülmüştür. Almanca bölümünde öğrenme stratejilerini kız öğrencilerin erkek öğrencilere göre daha sık kullandıkları gözlenirken, İngilizce bölümünde cinsiyete dayalı bir farklılık bulunmamıştır. Öğrenme stratejilerinin kullanımı ile öğrenme süresinin uzunluğu arasında anlamlı bir farklılık bulunmuş, öğrenme süresi uzadıkça strateji kullanımının arttığı ortaya Çı kmıştır.

Anahtar Kelimeler: LÖS, KÖS, Yeterlilik, Özerklik, İngiliz Dili Eğitimi, Alman Dili Eğitim 


\section{INTRODUCTION (GIRIŞ)}

Defined by Meare (1980) as 'a neglected aspect of language learning', since the beginning of 1970 s vocabulary learning has been the victim of this lack of interest. In terms of mastering a foreign or second language, having insufficient vocabulary knowledge undermines the language processing. When learners are asked to reflect on their learning process, they admit that they need to improve their knowledge of vocabulary. For developing more receptive (decoding) and practical (encoding) competence, learners state that they definitely need a wide range of vocabulary. Based on this point, no matter what level of their language proficiency having lexical gaps challenges learners both in understanding and actively using the second language (Read, 2000). Similarly, for more productive aspect of language, McCarthy points out that communication can meaningfully be sustained through vocabulary knowledge rather than grammar or pronunciation skills (McCarthy, 1990:viii). In addition to that, Goulden et al. (1990) state that without vocabulary knowledge learners can feel experience difficulty in reading and writing.

\subsection{Language Learning (LLS) and Vocabulary Learning Strategies (VLS) (Dil Öğrenme ve Kelime öğrenme Stratejileri)}

Learning a second or foreign language includes various types of learning as each individual learner employs different strategies in accordance with their learning styles and educational experiences (Brown, 1980:80). In this sense, according to O'Malley and Chamot (1990:1) LS can be seen as "the special thoughts or behaviors" that a person can address to understand, learn, and remember newly acquired knowledge. Additionally, Oxford (1990:8) states that these strategies also need to be "more transferable to new situations". Therefore, it is noteworthy to add that while designing a language learning environment, language teachers need to take into account the aspects like age, sex, aptitude, attitude, and motivation in order to orchestrate different language learning behaviors. In terms of developing taxonomy for LLS, Oxford (1989) designed a comprehensive inventory called SILL (Strategy Inventory for Language Learning). Being an all-inclusive inventory, SILL provides six categories of strategies as:

- Part A (Memory): e.g. thinking of relationships between old and new information, using rhymes, flashcards, visuals, and sounds.

- Part B (Cognitive): e.g. translating, dividing the new words into the parts, making summaries

- Part C (Compensation): e.g. guessing the meanings of new vocabulary, using synonyms, making up new words.

- Part D (Meta-cognitive): e.g. trying new ways for more effective learning, self-monitoring/assessment, setting clear goals, trying to be a better language learner.

- Part E (Affective): e.g. trying to be relaxed, encouraging one to speak target language, anxiety reduction.

- Part F (Social): e.g. asking native speakers to correct the person, practicing with other students.

Based on their roles in language learning, Oxford (1990) divides the abovementioned strategies into two basic categories as direct and indirect strategies. Direct LLS refer to the one that entails the direct use and "mental processing "of the target language (Oxford, 1990:37). Indirect ones, on the other hand, refer to the ones which have vital but indirect support for language learning. In this sense, 
while memory, cognitive, and compensation are listed under direct strategies, meta-cognitive, affective and social strategies are categorized as indirect strategies.

In the sense of the difference in VLS use between good language learners and the poor ones, O'Malley and Chamot (1990) put forward that successful learners employed a wide range of vocabulary strategies in contrast with the less successful ones.

\subsection{Schmitt's Taxonomy of Vocabulary Learning Strategies (Schmitt'in Kelime Öğrenme Stratejileri Taksonomisi)}

Among all taxonomies developed for VLS, Schmitt's (1997:207-8) categorization is viewed as one of the most comprehensive ones. Grouped under five parts as determination, social, memory, cognitive, and meta-cognitive strategies, the taxonomy was designed as below:

- The Determination Strategies Part (DET); Participants were asked whether they use dictionary, pictures, and keep word lists to guess the meaning of unknown words.

- The Social Strategies Part (SOC); Learners gave information about how to get the meaning of unknown words in relation with the agents of their social structure such as with their teacher or classmates.

- The Memory Strategies Part (MEM); Learners determined the strategies about how to use their faculty of mind to construct or store new words to actualize the learning.

- The Cognitive Strategies Part (COG); Strategies related to cognition that learners use to acquire new vocabulary.

- The Meta-cognitive Strategies Part (MET); Strategies related to the degree of self-awareness and understanding of their own learning process.

\subsection{Research Questions (Araştırma Soruları)}

The primary aim of the present study is to explore LLS and VLS preferences of language learners majoring in two different foreign language education programs as English and German Language Teaching. Besides the relationship in LLS and VLS use between a number of variables like gender, age, and grade, it is also designed to examine the differences in strategy use between good and poor language learners. Based on these points, this study tries to address the following research questions:

- Are there any differences in the use of LL (Language Learning) and VL (Vocabulary Learning) strategies among German and English language learners relating to gender?

- What are the most and least used LLS (Language Learning Strategies) and VLS (Vocabulary Learning Strategies) in German and English language?

- On which categories of learning and vocabulary learning strategies is L2 proficiency significantly effective?

- Does the length of L2 learning have a causal effect on LLS and VLS use in both target languages?

The present study firstly provides a research review that has focused on the role of vocabulary instruction and learning in language development; and secondly, it draws attention to the relation between the language learning and vocabulary learning strategies used by the learners of two different languages; namely, English and German. 


\section{RESEARCH SIGNIFICANCE (ÇALIŞMANIN ÖNEMİ)}

The review of the studies indicates that vocabulary knowledge has an essential role in improving receptive skills; namely, reading and listening, and productive skills; speaking and writing. In terms of providing improvement in foreign language there is a mutual dependence between the word knowledge and receptive competence (Anderson and Freebody, 1981; Huckin and Bloch, 1993; Nagy and Herman, 1987; Sternberg, 1987). That is to say, doing more readings and listening enriches one's vocabulary knowledge, building strong vocabulary skills enhances both the reading and listening comprehension. Even though there is limited research on the language learning potential provided by receptive and productive vocabulary instruction, the studies conducted in this area mostly point out that while receptive instruction supports the receptive vocabulary learning and vocabulary size, productively gained vocabularies through writing and speaking tasks are more effective on meaningful language learning and actively language use (Melka, 1997; Warring, 1997; Webb, 2005).

Taking into consideration the physical conditions and limited learning opportunities in language classrooms, it impossible to achieve the learning and the acquisition of all vocabulary in a second language only through vocabulary instruction. Thus, in order to acquire proficiency in target language, ESL and EFL learners definitely need to take the responsibility of vocabulary learning. A part of second language learning, promoting learner autonomy and active engagement by learners in vocabulary learning need to be emphasized in language classrooms and teacher training programs. According to Little's definition, learner autonomy refers to "a capacity- for detachment, critical reflection, decision making" (Little, 1991). In other words, autonomous language learner can be defined as the one who has individual self-awareness of own language skills and learning capacity and ready to take active responsibility in their learning. Regarding to the learners' role in constructing language education, some scholars (Benson, 2003; Gardner and MacIntyre, 1993; Holec, 1981) emphasize the learners' freedom to take the control of their own learning. Not being a complete control shift from teachers to learners, autonomy can be a maintained through promoting learners' willingness. In view of this, the following features can be attributed to autonomous and engaged learners. According to Omaggio (1978 cited in Wenden, 1998:41-42) students who tend to learn by themselves have several characteristics:

- First of all, they are aware of their learning styles,

- They also have good command of learning strategies,

- They participate actively in learning activities

- They are not afraid of making mistakes

- They give equal consideration to both language structure and use

- Finally, they do not easily get confused by unknown language items

As each learner has own point of view and different learning experiences, for language teachers it is reasonable to gain awareness about their students' learning and vocabulary acquisition strategies in order to gain them the aforementioned attributes of autonomous learner.

\section{RESEARCH DESIGN AND METHODS (ARAŞTIRMA DESENI VE METOTLAR)}

\subsection{Participants (Katılımcılar)}

The participants in this experiment are 44 male and 101 female learners of German language and 40 male and 70 female learners of 
English language. In total 255 EFL students accepted to take part in this study. Students are between 19 to 45 years old and studying at different grades.

\subsection{Instruments (Ölçme Araçları)}

Being practical to be conducted for a large number of participants, and thereby, easy to collect a large amount of information in a short time (Oxford, 1996; Cohen, 1998), as research instruments for collecting data, three questionnaires were conducted. The first questionnaire was designed to get data about the learners' background information, language learning, and vocabulary learning strategies. For the questionnaire related to the LLS, Oxford's (1987) Strategy Inventory for Language Learning (SILL) was adapted. This instrument includes forty-item regarding to the learners' preferences in language learning. The purpose of the second questionnaire is to explore VLS used by learners. For this purpose, Schmitt's (1997:207-8) taxonomy of vocabulary learning strategies was exploited. In these two questionnaires, as an indication for the frequency of strategy use, five level predefined ranges were used as given below:

- Never or almost never true of me

- Usually not true of me

- Somewhat true of me

- Usually true of me

- Always or almost always true of me

\subsection{Data Analysis (Veri Analizi)}

According to the Cronbach's alpha with reliability coefficient of .95, it was seen that our questionnaire had internal consistency and was reliable. For the data analysis, in order to see the interrelation between two variables the gender and LLS use and gender and VLS use in both German and English language, cross tabulation was conducted. In terms of identifying the degree of significance between the mean differences of two groups; namely, gender (male and female) and its significant effect on strategies use, independent t-test was run. Regression analysis was the next analysis which was used to estimate the causal relationship between the proficiency and strategies use. In other words, collected data was analyzed to see whether learners' proficiency level as being good or poor language learner had any causal effect on their use of strategy or not. For the final analysis, one-way ANOVA was conducted to relation between the length of language learning and the strategy use.

\section{FINDINGS (BULGULAR)}

\subsection{Findings Based on Descriptive Statistics (Tanımlayıcı İstatistiklere Dayalı Bulgular)}

Table 1 shows Language learning strategies which are most frequently used by German Language Teaching students. In this table the highest mean scores belong to items 23 (I pay attention when someone is speaking English), 24 (I try to find out how to be a better learner of English), 36 (If I do not understand something in English, I ask the other person to slow down or say it again) and 33 ( I notice if I am tense or nervous when I am studying or using English) respectively. Both male and female students mostly use item 23 which is paying attention when someone is speaking English, but mean scores of female students with respect to strategy use are higher than male students' mean scores. 
Table 1. Gender and the mostly used LLS cross tabulation in German language

(Tablo 1. Cinsiyet ve Almanca bölümünde sık kullanılan dil öğrenme stratejileri çapraz tablolaması)

\begin{tabular}{|c|c|c|c|c|c|}
\hline \multirow{2}{*}{\multicolumn{3}{|c|}{ German Language }} & \multicolumn{3}{|l|}{ Gender } \\
\hline & & & $\mathrm{M}$ & F & $\mathrm{T}$ \\
\hline PARTD-23 & Usually+ Always & Count-\% & $25(\div 56)$ & $71(\div 70)$ & $96(\div 66)$ \\
\hline PARTD-24 & Usually+ Always & Count-\% & $24(\div 54)$ & $69(\div 68)$ & $93(\div 64)$ \\
\hline PARTE-33 & Usually+ Always & Count-\% & $17(\div 38)$ & $65(\div 64)$ & $82(\div 56)$ \\
\hline PARTF-36 & Usually+ Always & Count-\% & $21(\div 47)$ & $66(\div 65)$ & $87(\div 60)$ \\
\hline
\end{tabular}

English Language Teaching students, on the other hand, most commonly use strategy 24 in Part D(I think of relationships between what I already know and new things I learn in English), and strategies 22 (I notice my English mistakes and use that information to help me do better), 1 ( I think of relationships between what I already know and new things I learn in English, 20 (If I can't think of an English word, I use a word or phrase that means the same thing), 29 (I think about my progress in learning English) respectively (Table 2). However, male students use these strategies more frequently than female students.

Table 2. Gender and the mostly used LLS cross tabulation in English language

(Tablo 2. Cinsiyet ve İngilizce bölümünde sık kullanılan dil öğrenme stratejileri çapraz tablolaması)

\begin{tabular}{|c|c|c|c|c|c|}
\hline \multirow{2}{*}{\multicolumn{3}{|c|}{ English Language }} & \multicolumn{3}{|l|}{ Gender } \\
\hline & & & $\mathrm{M}$ & $F$ & $\mathrm{~T}$ \\
\hline PARTA-1 & Usually+ Always & Count-o & $30(\div 75)$ & $48(\div 68)$ & $78(\div 70)$ \\
\hline PARTC-20 & Usually+ Always & Count- $\frac{\circ}{0}$ & $30(\div 75)$ & $47(\div 67)$ & $77(\div 70)$ \\
\hline PARTD-22 & Usually+ Always & Count- $\frac{\circ}{0}$ & $30(\div 75)$ & $50(\div 71)$ & $80(\div 72)$ \\
\hline PARTD-24 & Usually+ Always & Count- $\frac{\circ}{0}$ & $28(\div 70)$ & $60(\div 85)$ & $83(\div 75)$ \\
\hline PARTD-29 & Usually+ Always & Count-\% & $28(\div 70)$ & $48(\div 68)$ & $76(\div 69)$ \\
\hline
\end{tabular}

As is shown in Table 3 which is related vocabulary strategies students commonly use DET strategies. The highest mean scores in this group belong to DET 6, DET 3 and COG 34 (Taking notes) respectively. Namely, students frequently check for Ll cognate and use bilingual dictionary to learn vocabulary.

Table 3. Gender and the mostly used VLS cross tabulation in German language

(Tablo 3. Cinsiyet ve Almanca bölümünde sık kullanılan kelime)

\begin{tabular}{|c|c|c|c|c|c|}
\hline \multirow{2}{*}{\multicolumn{3}{|c|}{ German Language }} & \multicolumn{3}{|l|}{ Gender } \\
\hline & & & $\mathrm{M}$ & $\mathrm{F}$ & $\mathrm{T}$ \\
\hline $\mathrm{DET}-3$ & Usually+ Always & Count- $\%$ & $20(\div 45)$ & $64(\div 63)$ & $84(\div 57)$ \\
\hline $\mathrm{DET}-6$ & Usually+ Always & Count- $\frac{\circ}{0}$ & $28(\div 63)$ & $80(\div 79)$ & $108(\div 74)$ \\
\hline $\mathrm{COG}-34$ & Usually+ Always & Count-o & $17(\div 38)$ & $63(\div 62)$ & $80(\div 55)$ \\
\hline
\end{tabular}

When it comes to vocabulary learning strategies of English Language Teaching students, Table 4 reveals that they also commonly use the same DET strategies with German Language Teaching students. Besides, they use item MEM-18 which is associating the word with its coordinates. The mostly used vocabulary strategy by English Language Teaching students is COG-34 which is taking notes. 
Table 4. Gender and the mostly used VLS cross tabulation in English language

(Tablo 4. Cinsiyet ve İngilizce bölümünde sık kullanılan kelime öğrenme stratejileri çaproz tablolaması)

\begin{tabular}{|c|c|c|c|c|c|}
\hline \multirow{2}{*}{\multicolumn{3}{|c|}{ English Language }} & \multicolumn{3}{|l|}{ Gender } \\
\hline & & & $\mathrm{M}$ & $\mathrm{F}$ & $\mathrm{T}$ \\
\hline DET-3 & Usually+ Always & Count- $\frac{\circ}{0}$ & $27(\div 67)$ & $49(\div 70)$ & $76(\div 69)$ \\
\hline DET-6 & Usually+ Always & Count- $\frac{\circ}{\circ}$ & $24(\div 60)$ & $47(\div 67)$ & $71(\div 64)$ \\
\hline MEM-18 & Usually+ Always & Count- $\frac{\circ}{0}$ & $27(\div 67)$ & $43(\div 61)$ & $70(\div 63)$ \\
\hline $\mathrm{COG}-34$ & Usually+ Always & Count-\% & $28(\div 70)$ & $54(\div 77)$ & $82(\div 74)$ \\
\hline $\mathrm{DET}-3$ & Usually+ Always & Count-응 & $27(\div 67)$ & $49(\div 70)$ & $76(\div 69)$ \\
\hline
\end{tabular}

As indicated in Table 5 students rarely use part B strategies (B5: I start conversations in English, B7: I read for pleasure in English, and B8: I write notes, messages, letters or reports in English). Strategy 2 in part A which is using rhymes to remember new English words, and strategy 34 in part $E$ which is writing down language learning diary have also low mean scores in this group. In general, female students use learning strategies less frequently than male students.

Table 5. Gender and the least used LLS cross tabulation in German language

(Tablo 5. Cinsiyet ve Almanca bölümünde az kullanılan dil öğrenme Stratejileri çapraz tablolama)

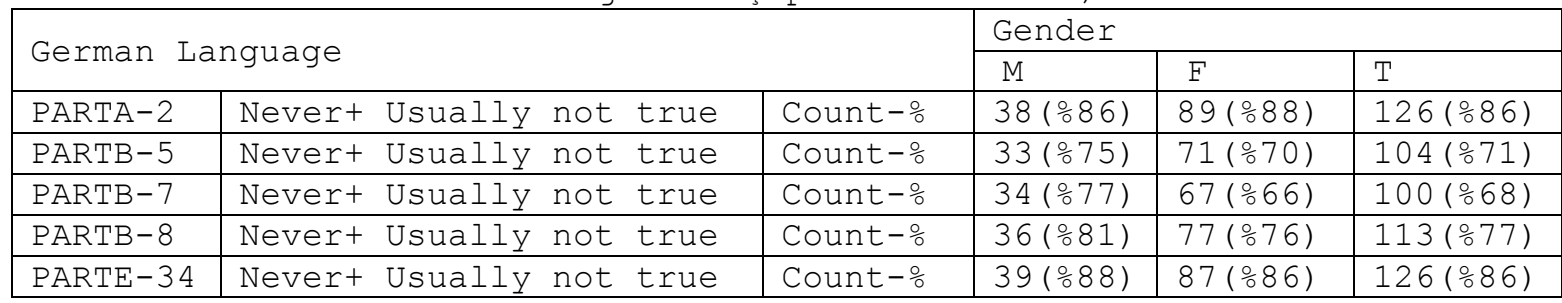

Compared to German students, it was found out that English students use learning strategies at a moderate level in general. Besides, they rarely prefer strategy 32 (I give myself a reward or threat when I do well in English) and strategy 34 (I write down my feelings in a language learning diary) in part $\mathrm{E}$ (Table 6).

Table 6. Gender and the least used LLS cross tabulation in English language

(Tablo 6. Cinsiyet ve İngilizce bölümünde az kullanılan dil öğrenme stratejileri çapraz tablolama)

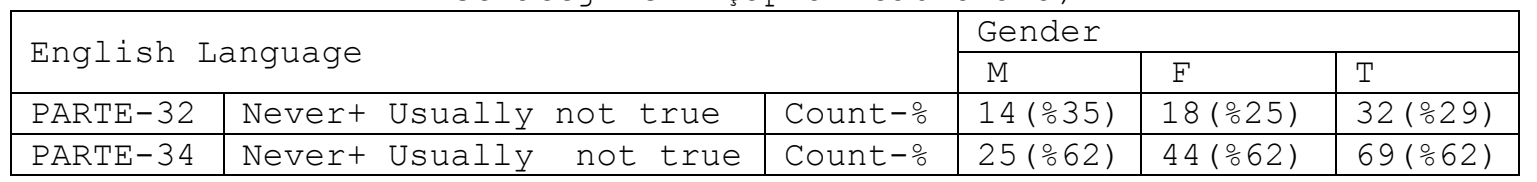

Table 7 reveals the least used strategies by German students. It was found that students rarely use soc-11(Asking teacher for paraphrase or synonym of new word), soc-12(Asking teacher for a sentence including the new word), and soc-14 (Discovery of new meaning through group work activity) strategies. They also do not prefer using mem-29 (Using cognates in study) and mem-30(learning the words of an idiom together) strategies. Lastly, det-9 (Using flash cards) and met37 (Testing oneself with word tests) strategies are among the ones that 
are less used by German language students. Moreover, female students were found to use these strategies less than male students.

Table 7. Gender and the least used VLS cross tabulation in German language

(Tablo 7.Cinsiyet ve Almanca bölümünde az kullanılan kelime öğrenme stratejileri çapraz tablolama)

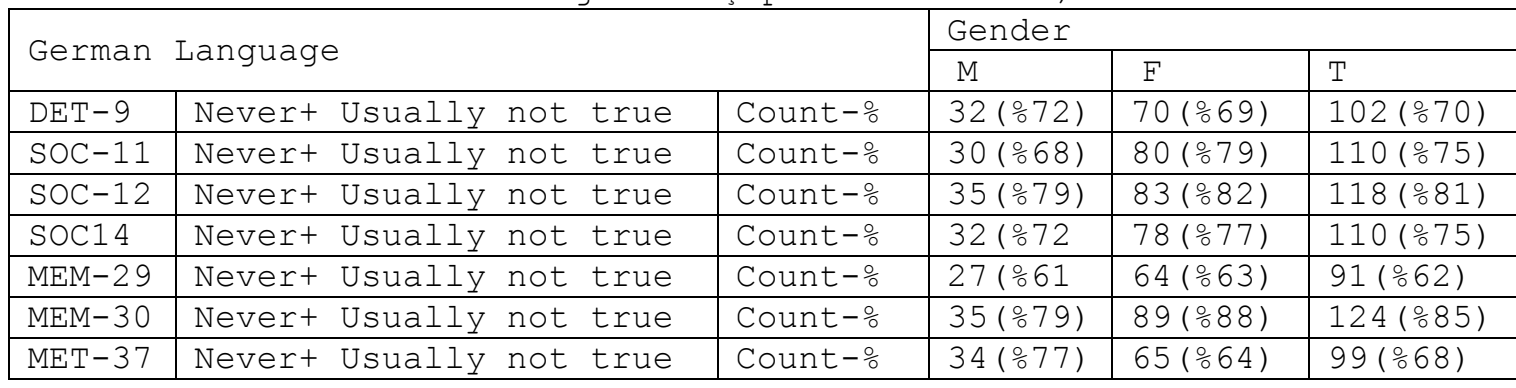

As it happens in German Language department, English language students rarely use soc- 12, mem-30 and det-9 strategies, too (Table 8). Besides, they do not use soc-10 (Asking teacher for an L1 translation), and soc-15 (interacting with native speakers) much. It is clear that both German and English language students are hesitant about using social strategies.

Table 8. Gender and the least used VLS cross tabulation in English language

(Tablo 8. Cinsiyet ve İngilizce bölümünde az kullanılan kelime öğrenme stratejileri çapraz tablolama)

\begin{tabular}{|c|c|c|c|c|c|c|c|c|}
\hline \multirow{2}{*}{\multicolumn{6}{|c|}{ English Language }} & \multicolumn{3}{|l|}{ Gender } \\
\hline & & & & & & \multirow{2}{*}{$\frac{M}{22(\div 55)}$} & \multirow{2}{*}{$\frac{F}{29(\% 41)}$} & \multirow{2}{*}{$\begin{array}{l}\mathrm{T} \\
51(\div 46)\end{array}$} \\
\hline DET-9 & Never & Usually & not & true & Count- $\frac{0}{\circ}$ & & & \\
\hline $\mathrm{SOC}-10$ & Never & Usually & not & true & Count-\% & $201 \div 50$ & $31(\div 44)$ & $51(\div 46)$ \\
\hline $\mathrm{SOC}-12$ & Never & Usually & not & true & Count-\% & $18(\div 45)$ & $22(\div 31)$ & $40(\div 36)$ \\
\hline $\mathrm{SOC}-15$ & Never & Usually & not & true & Count-\% & $18(\div 45)$ & $33(\div 47)$ & $51(\div 46)$ \\
\hline $\mathrm{MEM}-30$ & Never & Usually & not & true & Count-\% & $16(\div 40)$ & $23(\div 32)$ & $39(\div 35)$ \\
\hline
\end{tabular}

\subsection{Findings Based on Inferential Statistics}

\section{(Çıkarımsal İstatistiklere Dayalı Bulgular)}

Independent t-test was run to explore whether there is any difference in the use of LLS and VLS based on gender in German Language department. Table 9 shows that there is a meaningful difference between female and male students with respect to using the following strategies: $\operatorname{COG}(p=0,002)$, Part $A(p=0,025)$, Part $C$ $(p=0,027)$, Part D $(p=0,039)$. Female students used cognitive VLS more frequently than male students. It was also found that female students exploited language learning strategies in Part A, Part $C$ and Part D more than male students. As for Part B, Man-Whitney was applied to find out whether the use of strategies in Part $B$ differs based on gender because $\mathrm{p}$ value was found to be higher than $0,05(\mathrm{p}=0,068)$. 
Table 9. Independent t-test for gender and LLS-VLS use in German language

(Tablo 9. Cinsiyet ve Almanca bölümü öğrencileri DÖS-KÖS kullanımı bağımsız t-testi)

\begin{tabular}{|c|c|c|c|c|c|c|c|c|}
\hline & \multicolumn{2}{|c|}{$\begin{array}{c}\text { Levene's } \\
\text { Test for } \\
\text { Equality of } \\
\text { Variances } \\
\end{array}$} & \multicolumn{5}{|c|}{ t-test for Equality of Means } \\
\hline & & \multirow[t]{2}{*}{$\mathrm{F}$} & \multirow[t]{2}{*}{ Sig. } & \multirow[t]{2}{*}{$\mathrm{T}$} & \multirow[t]{2}{*}{$d f$} & \multirow{2}{*}{$\begin{array}{l}\text { Sig. } \\
(2- \\
\text { tailed })\end{array}$} & \multicolumn{2}{|c|}{$\begin{array}{l}\text { 95\% Confidence } \\
\text { Interval of the } \\
\text { Difference }\end{array}$} \\
\hline & & & & & & & Lower & Upper \\
\hline \multirow{2}{*}{$\begin{array}{l}\text { U } \\
\text { O }\end{array}$} & $\begin{array}{l}\text { Equal variances } \\
\text { assumed }\end{array}$ & 1,176 &, 280 & $-3,129$ & 143 &, 002 &,- 87884 &,- 19834 \\
\hline & $\begin{array}{l}\text { Equal variances } \\
\text { not assumed }\end{array}$ & & & $-2,934$ & 71,250 &, 004 &,- 90454 &,- 17265 \\
\hline \multirow{2}{*}{ 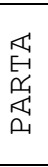 } & $\begin{array}{l}\text { Equal variances } \\
\text { assumed }\end{array}$ & 2,215 &, 139 & $-2,271$ & 143 &, 025 &,- 53029 &,- 03677 \\
\hline & $\begin{array}{l}\text { Equal variances } \\
\text { not assumed }\end{array}$ & & & $-2,116$ & 70,314 &, 038 &,- 55071 &,- 01634 \\
\hline \multirow{2}{*}{ 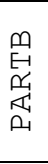 } & $\begin{array}{l}\text { Equal variances } \\
\text { assumed }\end{array}$ & 7,630 &, 006 & $-2,074$ & 143 &, 040 &,- 48602 &,- 01173 \\
\hline & $\begin{array}{l}\text { Equal variances } \\
\text { not assumed }\end{array}$ & & & $-1,855$ & 64,898 &, 068 &,- 51689 &, 01914 \\
\hline \multirow{2}{*}{ 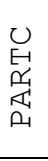 } & $\begin{array}{l}\text { Equal variances } \\
\text { assumed }\end{array}$ &, 395 &, 531 & $-2,228$ & 143 &, 027 &,- 57559 &,- 03437 \\
\hline & $\begin{array}{l}\text { Equal variances } \\
\text { not assumed }\end{array}$ & & & $-2,131$ & 74,227 &, 036 &,- 59018 &,- 01978 \\
\hline \multirow{2}{*}{ 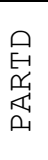 } & $\begin{array}{l}\text { Equal variances } \\
\text { not assumed }\end{array}$ & 2,151 &, 145 & $-2,078$ & 143 &, 039 &,- 63599 &,- 01592 \\
\hline & $\begin{array}{l}\text { Equal variances } \\
\text { not assumed }\end{array}$ & & & $-1,931$ & 69,884 &, 058 &,- 66272 &, 01080 \\
\hline
\end{tabular}

Table 10 reveals that there is not a significant difference in using Part B strategies based on gender: $\mathrm{P}=0,082 \quad \mathrm{p}>0,05$

In English Language department, on the other hand, no significant difference was found between strategy use and gender.

Table 10. Non-parametric test Mann-Whitney /gender and part b (Tablo 10. Cinsiyet ve bölüm b non-parametrik Mann-Whitney testi)

\begin{tabular}{|l|l|}
\hline & PART-B \\
\hline Mann-Whitney U & \\
\hline Wilcoxon W & 2807,500 \\
\hline Z & $-1,742$ \\
\hline Asymp. Sig. (2-tailed) &, 082 \\
\hline a. Grouping Variable: gender \\
\hline
\end{tabular}

Regression Analysis was applied to find out whether there is a relationship between success and strategy use of students in German language department (Table 11). The result showed that strategy use depends on success with R Square: $\% 59$. 
Table 11. Regression/Proficiency and LLS-VLS use in German language (Tablo 11. Yetkinlik ve Almanca bölümünde DÖS-KÖS kullanımı regresyonu)

\begin{tabular}{|l|l|l|l|l|}
\hline Model & $\mathrm{R}$ & $\mathrm{R}$ Square & Adjusted R Square & $\begin{array}{l}\text { Std. Error of the } \\
\text { Estimate }\end{array}$ \\
\hline 1 &, $243^{\mathrm{a}}$ &, 059 &,- 019 &, 57199 \\
\hline
\end{tabular}

By applying Regression-ANOVA, on the other hand, it was found that cause-effect relationship between strategy use and success was incidental (Table 12). Namely, the relationship was found to be insignificant: $\mathrm{P}=, 679 \mathrm{p}>0,05$

Table 12. Regression-ANOVA/ Proficiency and LLS-VLS use in German language

(Tablo 12. Yetkinlik ve Almanca bölümünde DÖS-KÖS kullanımı regresyonANOVA'SI)

\begin{tabular}{|c|c|c|c|c|c|c|}
\hline \multicolumn{7}{|c|}{ ANOVA $^{b}$} \\
\hline \multicolumn{2}{|c|}{ Model } & Sum of Squares & $\mathrm{Df}$ & Mean Square & $\mathrm{F}$ & Sig. \\
\hline \multirow{3}{*}{1} & Regression & 2,734 & 11 &, 249 &, 760 &, $679^{a}$ \\
\hline & Residual & 43,515 & 133 &, 327 & & \\
\hline & Total & 46,248 & 144 & & & \\
\hline
\end{tabular}

Table 13 shows that there is not a strong and significant causeeffect relationship between success and strategy use of English language students:

$\mathrm{R}$ square $=0,161$

It is evident that success does not have a considerable effect on strategy use of both German and English language students or vice versa.

Table 13. Regression/Proficiency and LLS-VLS use in English language (Tablo 13. Yetkinlik ve İngilizce bölümünde DÖS-KÖS kullanımı regresyonu)

\begin{tabular}{|l|l|l|l|l|}
\hline Model & $\mathrm{R}$ & $\begin{array}{l}\mathrm{R} \\
\text { Square }\end{array}$ & Adjusted R Square & $\begin{array}{l}\text { Std. Error of the } \\
\text { Estimate }\end{array}$ \\
\hline 1 &, $402^{\mathrm{a}}$ &, 161 &, 067 &, 45666 \\
\hline
\end{tabular}

In order to determine whether there are any significant differences between strategy use and length of language learning, Oneway ANOVA was applied (Table 14). The results showed that the use of strategies mentioned in Table 14 (MEM $p=, 023$, Part A $p=, 048$, Part B $\mathrm{P}=, 015$ and $\mathrm{p}<0,05)$ differs significantly according to the length of language learning in German Language department. The longer the duration that students are exposed the target language the more frequently they use the mentioned strategies above or vice versa. 
Table 14. One way ANOVA/length of language learning and LLS-VLS use in German language

(Tablo 14.Öğrenme süresi ve Almanca bölümü DÖS-KÖS kullanımı tek yön ANOVA'Sı

\begin{tabular}{|c|c|c|c|c|c|c|}
\hline \multicolumn{7}{|c|}{ ANOVA } \\
\hline & & $\begin{array}{l}\text { Sum of } \\
\text { Squares }\end{array}$ & $d f$ & $\begin{array}{l}\text { Mean } \\
\text { Square }\end{array}$ & $\mathrm{F}$ & Sig. \\
\hline \multirow[t]{3}{*}{ MEM } & Between Groups & 3,209 & 2 & 1,604 & 3,876 &, 023 \\
\hline & Within Groups & 58,785 & 142 &, 414 & & \\
\hline & Total & 61,994 & 144 & & & \\
\hline \multirow[t]{3}{*}{ PART-A } & Between Groups & 2,971 & 2 & 1,485 & 3,112 &, 048 \\
\hline & Within Groups & 67,792 & 142 &, 477 & & \\
\hline & Total & 70,763 & 144 & & & \\
\hline \multirow{3}{*}{ PART-B } & Between Groups & 3,740 & 2 & 1,870 & 4,337 &, 015 \\
\hline & Within Groups & 61,238 & 142 &, 431 & & \\
\hline & Total & 64,979 & 144 & & & \\
\hline
\end{tabular}

The results of the same test for English Language students showed that there was a significant difference between only Cog VLS and length of language learning:

$$
\mathrm{p}=, 025 \quad \mathrm{p}<0,05
$$

It is clear that more experienced students use cog VLS more frequently than less experienced students.

Table 15. One Way ANOVA/length of language learning and LLS-VLS use in English

(Tablo 15. Öğrenmesi süresi ve İngilizce bölümü DÖS-KÖS kullanımı tek yön ANOVA'sı)

\begin{tabular}{|c|l|l|l|l|l|l|}
\hline \multicolumn{2}{|c|}{ ANOVA } & $\begin{array}{l}\text { Sum of } \\
\text { Squares }\end{array}$ & df & $\begin{array}{l}\text { Mean } \\
\text { Square }\end{array}$ & F & Sig. \\
\hline \multirow{3}{*}{ COG } & Between Groups & 4,295 & 2 & 2,147 & 3,808 &, 025 \\
\cline { 2 - 8 } & Within Groups & 60,344 & 107 &, 564 & & \\
\cline { 2 - 7 } & Total & 64,639 & 109 & & & \\
\hline
\end{tabular}

\section{DISCUSSIONS (TARTIŞMALAR)}

For McDonough and Shaw(2003:56), having self-monitoring of one's own performance in language learning and searching for opportunities to actively use the newly learnt language is thought to be the key to achieve success in mastering a new language. In contrast with this view, the descriptive analysis of the data puts forward that learners majoring in German and English languages do not at all active in employing learning strategies. Out of 40 selected strategies, in both languages only 4 or 5 strategies are mostly used by learners in order to enhance their language learning. In German language learners mostly stated that they pay attention when someone is speaking German (\%66), try to find out how to be a better learner of German (\%64). Furthermore, in total $\div 56$ learners added that they were aware of own feelings about using target language even though there is difference between male (\%38) and female students (\%64). On the other hand, in English language, learners rated their learning strategies as building relationships between the newly learnt and old knowledge(\%70), using another word while not being able to find the right one (\%70), being aware of own mistakes and make good use of them to be a better language learner(기), trying to be a better learner of English(\%75), and thinking about own performance in learning English(\%69). In terms of using vocabulary learning strategies, both German and English 
language learners indicated that they mostly used the DET strategies of using bilingual dictionary with o74(German) and \%69(English) and taking notes with $\% 55$ (German) and 7 (English).

Gender cross tabulation with the least used LLS shows that learners of German language stated more strategies that they never or rarely used than the ones of English. According to this group, using rhymes to remember new words (\%86), having conversations in German (\%71), reading for pleasure (\%68), writing messages or letters in German (\%77), and keeping a diary to jot down their feelings (\%86) are the ones that they ignore mostly. According to English language learners, keeping a diary to jot down their feelings (\%62) is the least used LLS. For the effect of gender on the least used VLS, German language learners mostly stated that they never or rarely used mostly the strategies related to the soc category referring to the act of asking for help from or studying with other agents. Specifically, cross tabulation for SOC category provided that students less used the strategies of asking teacher for paraphrasing (\%75), asking teacher for sentence including the new word (\%81), and the discovery of the meaning of new word through group work (75). Besides these strategies, they also noted that learning the new words in idioms (85) was the strategy that they at all did not employ in their learning process. Similar to German language students, English language learners also reflected that the SOC category strategies were also the ones that they most of the time ignored. Furthermore, like German group, using flashcards (\%46) and learning the words in idioms (\%35) are the ones that they indicated that they did not at all apply.

Additionally, as an inferential statistics the independent $t-$ test which is run to get information whether LLS and VLS use may be differed in terms of gender. In German Language, at the end of analysis, based on the p-values it is seen that gender means in COG (Cognitive vocabulary strategies) and in LLS including Part-A (Memory), Part-B (Cognitive), Part-C (Compensation), and Part-D (Metacognitive) are significantly different. To simply put, we can conclude that female learners of German language tended to use more strategies than the male ones. On the other hand, independent t-test analysis for English language learners did not show any significant difference between gender and LLS and VLS use. Moreover, regression analysis for the causal effect of proficiency level of the learners on their application of LLS and VLS use indicates that strategy use among German Language learners 059 depends on their proficiency level. That is to say, good language learners of German employ more strategies. On the other side, for English Language this dependence degree is only o16. The values given by ANOVA analysis shows that this dependence is not significant but coincidental. Lastly, one way ANOVA analysis put forward that according to German language learners, the longer the length time that the learners are involved in that language, the more they show tendency to use the VLS of MEM(Memory) which refers to the strategies of grouping, connecting, and associating the new word with others, and the LLS of Part-A(Memory) which requires thinking of relationship between the old and new knowledge and Part-B(Cognitive) that includes the strategies of translating, summarizing, and dividing the word into its parts. Then again, for English language learners the same analysis provides that the length of time dealing with English has only effect on the VLS strategy of COG which emphasizes the strategies of verbal, written repetition, studying with word lists, or using flashcards etc. 


\section{CONCLUSIONS (SONUÇLAR)}

Based on the findings of the study, it has been seen that learners of both languages frequently exploit meta-cognitive learning strategies which mean that they are eager to regulate their learning process. Moreover, students of German Language claimed that they often use social strategies to learn German, while English language students made good use of compensation strategies. With regard to using vocabulary learning strategies, learners of both languages commonly use cognitive strategies such as doing repetition, taking notes etc. to learn vocabulary. On the other hand, learners of both languages rarely use social strategies. They are hesitant about asking for help from their teacher and friends. Also, they are reluctant to interact with native speakers. Besides, students seldom use Determination and Memory strategies.

In order to see whether gender has any considerable effect on strategy use, Independent t-test was applied. It was found that female students use both LLS and VLS more frequently than male students in German Language Department. However, no significant difference was found between male and female students in terms of strategy use in English Language Teaching Department. Surprisingly, it was found that language proficiency has no considerable effect on strategy use in both German Language department and English Language department. On the other hand, more experienced students tended to use learning strategies more frequently than less experienced students in both department.The findings of the present study give descriptive and inferential statistics of strategy use in German Language and English Language Department. However, more exploratory studies are needed about learning strategies in the field of SLA to get a clear idea about how effective these strategies are used by learners. Furthermore, strategy training courses should be delivered to both teachers and students to get the maximum benefit from learning process.

\section{REFERENCES (KAYNAKLAR)}

1. Anderson, R.C. and Freebody, P., (1981). Vocabulary Knowledge. In J. T. Guthrie (Ed.), Comprehension and teaching: Research Reviews (pp. 77-117). Newark, DE: International Reading Association.

2. Benson, P., (2003). Learner Autonomy in the Classroom. In D. Nunan (ed.), Practical English Language Teaching. New York: McGraw Hill, 289-308.

3. Gardner, R., and MacIntyre, P., (1993). A student's Contributions to Second-Language Learning. Part II: Affective Variables. Language Teaching 26. Cambridge: Cambridge University Press. DOI: 10.1017/S0261444800000045, P: 1-11.

4. Goulden, R., Nation, P., and Read, J., (1990). How Large a Receptive Vocabulary Be? Applied Linguistics. 11, 4: 341-63.

5. Holec, H., (1981). Autonomy and Foreign Language Learning. Oxford: Pergamon Press for the Council of Europe.

6. Huckin, T. and Bloch, J., (1993). Strategies for Inferring Wordmeanings in Context: A Cognitive Model. In T. Huckin and M. Haynes (eds.), Second Language Reading and Vocabulary Learning (pp. 153-178). Norwood, NJ: Ablex Publishing Corporation.

7. Little, D., (1991). Learner Autonomy I: Definitions, Issues, and Problems. Dublin: Authentik.

8. McCarthy, M.J., (1990). Vocabulary. Oxford: Oxford University Press. 
9. Meara, P., (1980). Vocabulary Acquisition: A Neglected Aspect of Language Learning. Language Teaching and Linguistics: Abstracts 13. DOI: $10.1017 / \mathrm{S} 0261444800008879$, P: 221-246.

10. Melka, F., (1997). Receptive vs. Productive Aspects of Vocabulary. In N. Schmitt and M. McCarthy (Eds.), Vocabulary: Description, Acquisition and Pedagogy (pp. 84-102). Cambridge, UK: Cambridge University Press.

11. Nagy, W.E. and Herman, P.A., (1987). Breadth and Depth of Vocabulary Knowledge: Implications for Acquisition and Instruction. In M. G. Mckeown and M. E. Curtis (Eds.), The Nature of Vocabulary Acquisition (pp. 19-51). Hillsdale, NJ: Erlbaum.

12. Omaggio, A., (1978). Successful Language Learners: What Do We Know about Them? ERIC / CLL News Bulletin, May, 2-3.

13. O'Malley, J.M. and Chamot, A.U., (1990). Learning Strategies in Second Language Acquisition. Cambridge, U.K.: Cambridge University Press.

14. Oxford, R.L., (1989). Use of language Learning Strategies: A Synthesis of Studies with Implications for Strategy Training. System, 17/2. DOI: 10.1016/0346-251X (89)90036-5, P: 235-247.

15. Oxford, R.L., (1990). Language Learning Strategies: What Every Teacher Should Know. Boston: Heinle and Heinle.

16. Schmitt, N., (1997). Vocabulary Learning Strategies. In Schmitt, N., and McCarthy, M. Vocabulary: Description, Acquisition and Pedagogy. Cambridge: Cambridge University Press.

17. Read, J., (2000). Assessing Vocabulary. Cambridge: Cambridge University Press.

18. Webb, S., (2005). Receptive and Productive Vocabulary Learning: The Effects of Reading and Writing on Word Knowledge. SSLA. 27. DOI: $10.1017 /$ S0272263105050023, P: 33-52.

19. Wenden, A., (1998). Learner Strategies for Learner Autonomy. Great Britain: Prentice Hall. 